\title{
Research on the Task-based Teaching System of College English Curriculum
}

\author{
Ge Zhang ${ }^{1, *}$ and Chunying $\mathrm{Li}^{1}$
}

\author{
${ }^{1}$ The College of Post and Telecommunication of Wuhan Institute of Technology, Wuhan, Hubei 430073, China \\ *Corresponding author. Email:92000145@wit.edu.cn
}

\begin{abstract}
In order to improve the quality and efficiency of college English teaching, this work proposed a new teaching system of task-based college English curriculum. The research took the college English teaching as the research object. Firstly, this work sorts out the problems existing in the current college English teaching system, and then adopts the comparative analysis method to summarize the remarkable characteristics of the task-based teaching system of college English, finally, puts forward the idea of constructing a task-based college English teaching system from the perspective of systematic theory. The teaching practice verified the scientific nature and effectiveness of this study.
\end{abstract}

Keywords: Task-based; College English; Curriculum teaching; Teaching system

\section{INTRODUCTION}

Curriculum teaching system is the key to achieve curriculum teaching goals, but due to the lagging ideas of limited conditions, rigid teaching mode and objective factors, the current college English curriculum system has some problems, such as unreasonable content, inflexible method and scientific evaluation, which restrict the benefit of talent training to some extent. Based on the current situation of the college English curriculum teaching system, this work systematically put forward the idea of building a task-based college English curriculum teaching system combined with years of experience in college English teaching, and made active attempts. The practice has proved that this study is of great theoretical and practical significance for improving the teaching model of college English course, improving the teaching quality of college English course and promoting the all-round development of students' English ability.

\section{MAIN PROBLEMS EXISTING IN THE CURRENT TEACHING SYSTEM OF COLLEGE ENGLISH CURRICULUM}

After long engaged in college English curriculum teaching practice and research, the author found that the current teaching system of college English curriculum mainly has the following problems:

\subsection{The Teaching Content is Not Reasonable}

Teaching content is not only an important part of the teaching system, but also the foundation and premise of other elements in the teaching system. Therefore, a scientific and reasonable college English course teaching system must be supported by scientific and reasonable teaching contents. However, the research shows that the teaching materials used in different college English courses are similar. For example, some independent colleges and non-independent colleges use exactly the same English teaching materials, but in fact, the two are very different in terms of students' English foundation and course teaching objectives. Therefore, using the same teaching materials is obviously not conducive to talent cultivation. Although teachers give targeted correction in teaching activities for the above problems, this phenomenon is still common, which can not meet the objective and urgent need of college English curriculum teaching for talent training requirements.

\subsection{The Teaching Method is Not Flexible}

The teaching method of college English curriculum is the general term of the behavior methods adopted by teachers and students in the college English course teaching to realize the teaching objectives and requirements of the course. It can be seen that the choice of teaching methods has a direct impact on the teaching effect, but according to the practice and research, it is found that the current college English teaching method is generally single phenomenon. As shown in Fig. 1, especially almost all the current college English teaching use the teaching method. However, the discussion method which cultivates the spirit of cooperation, stimulates the interest in learning and improves the independence of learning, and the driving method which cultivates the ability to find, analyze and solve problems are rarely involved. Thus, the effectiveness of classroom teaching of college English curriculum is greatly affected. 


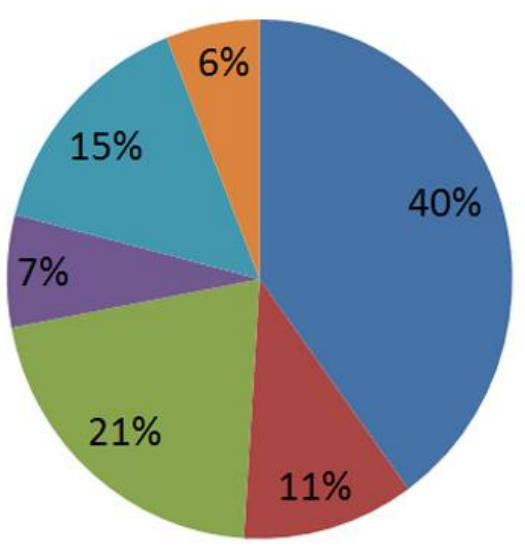

Teaching method

Discussion method
Reading guidance method

Practice method

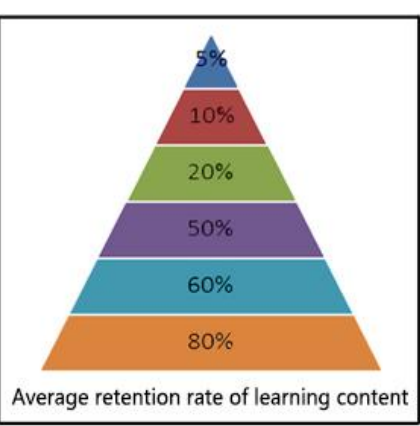

Listening and speaking method

Task-driven method

Figure 1. Common methods of English teaching in a college

\subsection{The Teaching Evaluation is Not Scientific}

The practice has proved that college English teaching evaluation plays an important role in stimulating learning interest, judging teaching quality and regulating teaching behavior [1]. However, according to the research, it is found that the current college English course teaching evaluation has many problems, such as single evaluation means, rigid evaluation standards and lack of evaluation function, as shown in Table 1. For example, in terms of evaluation form, it focuses on the evaluation of learning results, but ignores the evaluation of the teaching process; in terms of the evaluation content, it focuses on the evaluation of common content, but ignores the evaluation of the different demands of college English course teaching for different talents training objectives; in terms of the evaluation of objects, it focuses on the assessment of students' learning effect, but ignores the evaluation of teacher teaching effect.

Table 1. Problems in evaluating the college English curriculum evaluation

\begin{tabular}{|c|c|c|c|c|c|}
\hline Serial number & Existing problems & \multicolumn{4}{|c|}{ Standard and proportion } \\
\hline \multirow{2}{*}{1} & \multirow{2}{*}{ Evaluation means } & Diverse & Common & To be improved & Single \\
\cline { 3 - 6 } & & $7.90 \%$ & $17.30 \%$ & $32.30 \%$ & $42.50 \%$ \\
\hline \multirow{2}{*}{2} & \multirow{2}{*}{ Evaluation standards } & Scientific & Common & To be improved & Rigid \\
\cline { 3 - 6 } & $12.50 \%$ & $21.70 \%$ & $26.60 \%$ & $39.20 \%$ \\
\hline \multirow{2}{*}{3} & \multirow{2}{*}{ Evaluation function } & Notable & Common & To be improved & Missing \\
\cline { 3 - 6 } & & $9.80 \%$ & $25.60 \%$ & $38.20 \%$ & $26.40 \%$ \\
\hline \multirow{2}{*}{4} & \multirow{2}{*}{ Evaluation positioning } & Explicit & Common & To be improved & Vague \\
\cline { 3 - 6 } & & $7.70 \%$ & $12.60 \%$ & $31.30 \%$ & $48.40 \%$ \\
\hline \multirow{2}{*}{5} & \multirow{2}{*}{ Evaluation item } & Reasonable & Common & To be improved & Malformed \\
\cline { 3 - 6 } & & $15.20 \%$ & $30.80 \%$ & $21.10 \%$ & $32.90 \%$ \\
\hline
\end{tabular}

\section{THE OUTSTANDING}

\section{CHARACTERISTICS OF THE TASK-}

\section{BASED TEACHING SYSTEM OF} COLLEGE ENGLISH CURRICULUM

Task-based teaching is a new teaching mode, and its essence is to make the teaching process task based [2]. Therefore, it is of very important significance to introduce the concept of "task-based" teaching into the teaching system of college English courses. The main features are as follows:

\subsection{Improve the Autonomous Learning of Students}

In task-based college English teaching activities, teachers mainly design specific and operational tasks around specific English application environment, while students complete the tasks through various language activities such as expression, communication, and inquiry. It can be seen 
that task-based English curriculum teaching system not only properly handles the relationship between basic knowledge, language ability and professional application through adhering to the talent cultivation objective, but also establishes the subject position of students' learning while improving students' comprehensive application ability of English, so that students can have strong learning autonomy.

\subsection{Enhance the Pertinence of Teaching Content}

"Task-based" teaching requires that any teaching task should be endowed with substantive content, which is specifically reflected in behaviors and activities that need to be performed by students [3]. Therefore, for the "taskbased" college English course teaching system, its teaching content must be task-based, otherwise "task-based" college English course teaching is difficult to carry out and implement. This requires that the teaching contents of college English courses should be selected according to different teaching needs and adhere to the principle of stimulating interest, improving application ability and improving comprehensive quality. Thus it can be seen that the task-based teaching content of college English course is highly targeted.

\subsection{Promote the Diversity of Teaching Methods}

In task-based teaching, not only each student has his own task to complete, but also it involves a lot of interpersonal communication [4]. Therefore, task-based college English teaching is more abundant in teaching methods than traditional college English teaching. For example, teachers can create space-time environment, allowing students to complete specific tasks in specific situations, so as to mobilize the internal motivation of students' learning. The teaching task can not only be applied to classroom teaching, but also can be expanded to extracurricular learning, so that classroom teaching and extracurricular learning are integrated, and students can immerse themselves in college English teaching in an all-round and multi-angle.

\subsection{Highlight the Development of Teaching Process}

Compared with the traditional teaching activities, in taskbased teaching activities, several tasks of a class should be related to each other and have a unified goal orientation. Students can achieve the expected teaching aim by completing the corresponding task, that is to say, in the task-based college English teaching activities, teachers should not only pay attention to the result evaluation of the whole teaching, but also pay attention to the process evaluation of students' completion of each task. At the same time, the teaching task should be adjusted dynamically according to the learning characteristics and training objectives of students, so as to improve and perfect task-based college English teaching.

\section{THE CONSTRUCTION OF TASK- BASED TEACHING SYSTEM FOR COLLEGE ENGLISH CURRICULUM}

The construction of task-based college English teaching system is a systematic engineering. In addition to following the basic principles of task-based teaching, some efforts should be made in the following aspects.

\subsection{Selection of Teaching Content}

This work argues that the task-based college English teaching system should pay attention to consistency, inheritance and progression in the selection of teaching content. Specifically, the teaching content system should include three modules: general basic English, professional basic English and professional English. Among them, the general basic English module mainly develops students' basic English language skills; professional English is a combination of professional skills and English language according to the training objectives of different professionals. It not only has the basic rules of English teaching, but also has content characteristics and knowledge system of professional education. At the same time, according to the law in the ladder of teaching activities, professional English can be further divided into basic English and professional skills. Basic professional English is a professional basic course taught in English based on basic professional knowledge, highlighting the professional premise, while professional English is a professional course taught in English based on the needs of the professional development of the subject, highlighting the professional development. In short, general basic English, professional basic English and professional English and other three modules together constitute the task-based college English curriculum from low to advanced ladder teaching content system. Therefore, the college English teaching is not only guided by "task" and embodies the "practical" nature of the course, but also provides a personalized path for the comprehensive development of students' ability and quality by relying on the "task" platform.

\subsection{Application of Teaching Methods}

Compared with the traditional college English curriculum teaching, the construction of the task-based college English curriculum teaching system should put forward new requirements for the application of teaching methods. For one thing, it is determined by the characteristics of the task-based teaching system itself; for another, the 
corresponding teaching method is also an important part of the task-based college English course teaching system [5]. Specifically, in the task-based college English teaching system, teachers are no longer the center of English teaching in the traditional sense, but guide students to learn as the host or guide, mainly to help students determine learning goals, make learning plans, guide students to selfevaluation and reflection. For example, in listening teaching, teachers can not only arrange listening tasks in class, but also targeted listening tasks after class. At the same time, teachers can conduct appropriate checks, so that students can develop good listening habits [6]. Thus, building a task-based college English curriculum teaching system can not only bring about the change of the roles of teachers and students, but also can better reflect the teaching concept of "teaching-oriented and learningoriented". The traditional teaching method of "teacher speaking, students listening, teacher reading and students writing" should be transformed into a "task-driven, problem-oriented and proactive" classroom teaching method with "guidance, training, communication and mentoring" as links, so as to improve the teaching efficiency of college English course.

\subsection{Organizing Form of Teaching}

Task-based teaching focuses on driving students to learn independently through tasks, which requires that taskbased college English teaching should not continue to follow the traditional teaching organization, but fully combine the characteristics and requirements of task-based college English teaching, so as to develop a new teaching organization. Specifically, one form is to promote smallclass teaching. At present, in most colleges and universities, college English courses are taught in large classes. The large number of students not only makes it difficult to fully carry out teaching activities, but also seriously affects the teaching effect. Task-based college English curriculum is usually a collective and cooperative activity, usually in the form of interaction for the implementation of the task, which requires task-based college English curriculum to reform the traditional teaching organization form and implement small class teaching. Therefore, it can truly achieve the task to mobilize students' classroom participation rate, and stimulate students to complete the task of the internal power. Another form of teaching is hierarchical teaching. A basic premise of the construction of the task-based university English curriculum teaching system is to teach students in accordance with their aptitude. Imagine if the English level of uneven students are arranged in the same teaching class to complete the same task, they are bound to contain and influence each other. Therefore, it is necessary to carry out a comprehensive scientific evaluation of the students' English foundation, divide it into different levels, and formulate the corresponding teaching plan, so as to ensure the smooth implementation of the task-based college English teaching.

\subsection{Implementation of Teaching Evaluation}

A key link of task-based teaching is to decompose the curriculum into several tasks. Through the evaluation of students' completion of the task, it can not only promote students to learn, but also test the teaching effect. Thus it can be seen that attaching importance to process evaluation is the essential requirement of task-based college English teaching system. This requires the task-based college English course teaching evaluation to strengthen the examination of students' comprehensive practical ability of listening, speaking, reading, writing and translating in accordance with the ability system and personnel training requirements, so as to promote the all-round development of students' English ability and quality. In terms of evaluation timing, the traditional one-time evaluation should be changed to establish a dynamic evaluation throughout the whole course of college English teaching, so as to guide students to form a benign English learning habit. In terms of evaluation organization, it is divided into dynamic tracking and final course evaluation. Dynamic tracking evaluation is mainly to effectively monitor the process of students learning college English, and final course evaluation is mainly to conduct a comprehensive test of the results of students learning college English. In terms of the evaluation object, it not only includes the evaluation of students' learning, but also includes the evaluation of teachers' teaching. The evaluation of students is to test the effect of task-based college English course, and the evaluation of teachers is to urge teachers to optimize the teaching content, improve the teaching method and perfect the task setting.

\section{ANALYSIS OF EXPERIMENTAL RESULTS}

Practice is the sole criterion for testing truth. In recent years, the author tried the results of this study in some classes and found that students in these classes not only performed better than students in other classes using the traditional college English teaching system, but also achieved balanced development in listening, speaking, reading, writing, translation and other aspects, as shown in Fig. 2. Through further excavation, it can be found that, first, influenced by traditional teaching habits, students' acceptance of task-based college English course teaching is a gradual process. Basically, it is not until the second semester of 2020 that class A gradually adapts to it; second, according to the English results of classes A and B in different semesters, the task-based college English teaching system is of great benefit to the improvement of listening and speaking ability in English teaching; third, compared with Class B, Class A made great progress in English performance in the later period, which indirectly proved that the task-based college English teaching system could stimulate students' inner motivation for learning. Thus, the task-based college English curriculum teaching system can not only promote students to the basic knowledge of 
English to absorb, but also promote the students' English application ability of ascension. It has a remarkable effect on solving some problems in current college English course teaching, which effectively proves that the construction of task-based college English course teaching system is scientific and necessary.

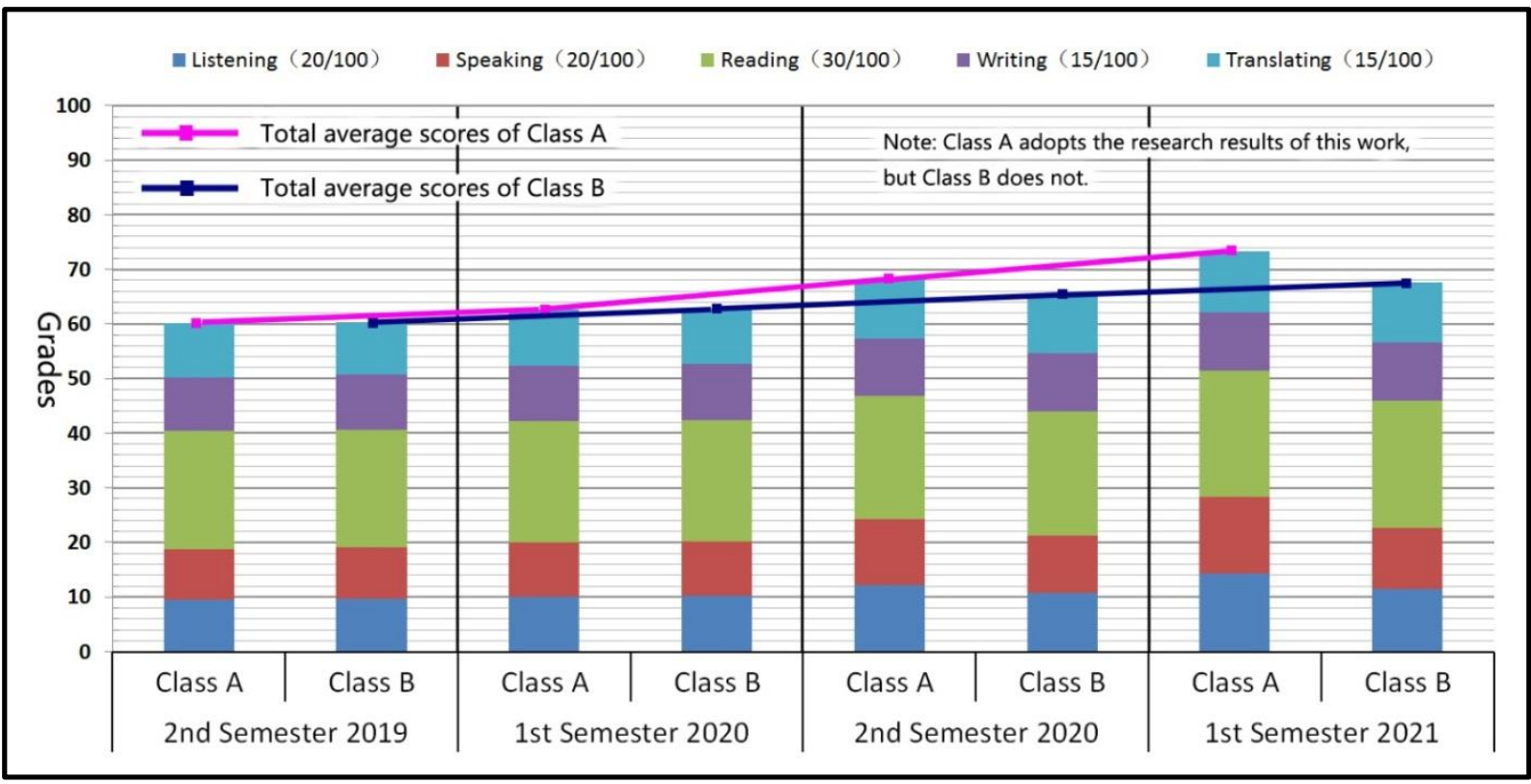

Figure 2. Experimental results of task-based college English teaching

\section{CONCLUSION}

For a long time, influenced by the traditional examoriented education mode, college English teaching generally exists the phenomenon that "teachers are busy, students are tired, the teaching time is long, the effect is poor, and emphasis on the examination, not the ability". It not only hinders the benign development of college English teaching, but also affects and restricts the quality of talent training. Task-based college English curriculum teaching system is based on the task-based teaching theory to probe into the teaching system of college English curriculum from the aspects of teaching content, teaching methods, teaching forms and teaching evaluation. It is not only conducive to improving the traditional college English teaching mode, but also conducive to improving the quality of college English teaching, and more conducive to implementing the teaching concept of "teaching-oriented, learning-oriented". In short, the construction of task-based college English teaching system is not only a great change to the current college English teaching, but also a beneficial attempt to the college talent training model.

\section{REFERENCES}

[1] Ren Xuejiao. Research on College English Classroom Teaching Strategies Based on Core Discipline Literacy [J]. English Square, 2019 (07).

[2] Xiong Yuhong. Classroom Practice of Task-based Teaching Method in College English Reading Teaching [J]. Industrial and Science Tribune, 2020 (01).

[3] Liu Huaqiang. Application and Exploration of the Task-driven Teaching Method in the Basic Engineering Course [J]. Education Modernization, 2019 (06).

[4] Li Niannian. Application of Task-based Teaching in Japanese Grammar Teaching [J]. Journal of Yanbian Education College, 2020 (02).

[5] Zheng Zhen. The Application of Task-driven Situational Teaching Method in Military English Listening and Speaking Teaching [J]. Overseas English, $2021(02)$.

[6] Liu Panpan. Research on Task-based English Grammar Teaching [J]. Campus English, 2018 (11). 